\title{
Effects of ambient noise on the metabolic level of Crangon crangon (Decapoda, Natantia)
}

\author{
Michèle Regnault and Jean-Paul Lagardère \\ Laboratoire CNRS, Station Biologique, F-29211 Roscoff, France \\ Station Marine d'Endoume, Antenne de la Rochelle, C.R.E.O., F-17000 La Rochelle, France
}

\begin{abstract}
Preliminary observations indicated that the shrimp Crangon crangon (L.) appeared to be affected by the level of the ambient noise expressed as sound pressure. The significance of its metabolic response was studied by comparing its ammonia excretion rate under usual laboratory conditions $\mathrm{E}\left(=+25 \mathrm{~dB} \mu \mathrm{bar}^{-1}\right)$ to its rate under sound-proof conditions $\mathrm{C}\left(=-4 \mathrm{~dB} \mu \mathrm{bar}^{-1}\right)$. The relationship between these 2 measured excretion rates was expressed by the equation: $\mathrm{E}=1.225 \mathrm{C}$ $0.01329(\mathrm{r}=0.81)$. Thus a mean $30 \mathrm{~dB}$-increased sound pressure led to a $22 \%$ increase of the ammonia excretion rate; simultaneously, a $15 \%$ increase of the $\mathrm{O}_{2}$ consumption rate was noticed. The metabolic response to a high ambient noise level was fully expressed within a few hours and there was no evidence for any adaptative reduction of metabolic rates over the period of observation ( $5 \mathrm{~d}$ ). Shrimpsize and/or -age as much as the noise spectrum should be taken into account when metabolic responses of $C$. crangon to its acoustic environment are considered.
\end{abstract}

\section{INTRODUCTION}

In decapod crustaceans, body and appendage surfaces are provided extensively with sensory hairs of various shapes and sizes. The hairs occur isolated, in groups or in complex structures. Their function is not always known (Debaisieux, 1949). Some of these sensory units, the mechanoreceptors, respond to vibrations transmitted in the environment - whether air, substratum (Cohen and Dijkgraaf, 1961; Horch, 1971; Salmon et al., 1977) or water (Laverack, $1962 \mathrm{a}$, b; Tazaki and Ohnishi, 1974; Vedel and Clarac, 1976; Tazaki, 1977: Chichibu, 1978 a, b; Tautz and Sandeman, 1980; Tautz et al., 1981). They allow the animal to collect precise information on the characteristics of an acoustic stimulation in a near field: frequency, particle displacement, velocity, direction ... (Tazaki, 1977). Electrophysiological studies have shown that these receptors respond only to a narrow frequency band (10 to 70 $\mathrm{Hz}$ ) and, depending on the species, their sensitivity is at a maximum from 40 to $70 \mathrm{~Hz}$ (Vedel and Clarac, 1976; Tazaki, 1977; Tautz et al., 1981). Besides these mechanoreceptive units, Tautz et al. (1981) found in crayfish a more complex structure: the flagellumfeathered hair system that allows the analysis of a wider frequency range ( 40 to $150 \mathrm{~Hz}$ at least) with a very low threshold. This organ, which is probably found in many Natantia (Foxton, 1969), is supposed to detect moving objects such as approaching predators, prey or congeners. According to these peculiar sense organs and to their known physiological properties in decapods, it is to be expected that the shrimp Crangon crangon (L.) can sense variations in environmental sound pressure at low frequencies (below $1000 \mathrm{~Hz}$ ).

At sea, when the weather is calm and at shallow depths, the sound pressure at frequencies between 20 and $1000 \mathrm{~Hz}$ is generally low. According to Wenz (1962), Chapman and Hawkins (1973), Buerkle (1977), the level of ambient noise lies in the range -50 to -5 $\mathrm{dB} \mu \mathrm{bar}^{-1} \mathrm{~Hz}^{-1}$. In the Seudre estuary, where Crangon crangon live, the ambient sound pressure recorded near the sediment at $1 \mathrm{~m}$ water depth and at a sea-state zero ranged from -49 to $-14 \mathrm{~dB} \mu \mathrm{bar}^{-1} \mathrm{~Hz}^{-1}$ between 20 and $1000 \mathrm{~Hz}$ (Lagardère, 1982). Obviously, the noise level in the sea - being subject to meteorological, tidal, and human effects, particularly in industrialized or touristic estuarine areas - is rather variable. In contrast, the ambient sound pressure under laboratory conditions is usually much higher (from -28 to $+5 \mathrm{~dB}$ $\mu \mathrm{bar}^{-1} \mathrm{~Hz}^{-1}$ in the 20 to $1000 \mathrm{~Hz}$ frequency range). Much of the noise comes from machinery, pumps and compressors associated with the aquarium, footfalls, 
doors opening and closing etc... (Hawkins and Anthony, 1981). This increased sound level, permanently imposed on the animals, stimulates their mechanoreceptors liable to induce a stress-state. Preliminary studies in this field have shown that high sound level causes in C. crangon some modifications in behaviour (increased cannibalism) and a growth delay (Lagardère and Spérandio, 1981). Furthermore, noticeable physiological changes were observed in oxygen consumption and ammonia release (Lagardère and Regnault, 1980).

These first results encouraged us to study the metabolic response of Crangon crangon to ambient noise level in order to verify and test our previous observations. The ammonia excretion and oxygen consumption rates of $C$. crangon were used to study its response to either the usual laboratory sound pressure or a reduced sound pressure in a soundproofed box. In C. crangon, ammonia accounts for 94 to $98 \%$ of the total nitrogen excreted and its release through the gill epithelium is continuous (Regnault, 1981b). Therefore, ammonia excretion rate is a good indicator of the nitrogen metabolism level and was selected as response criterion. In addition, continuous observations were run for 4 to $5 \mathrm{~d}$ in order to detect a possible adaptative process in the shrimp to the laboratory background noise level. During the second part of this study, ammonia excretion and oxygen consumption rates were measured simultaneously.

\section{MATERIALS AND METHODS}

Shrimp between 20 and $25 \mathrm{~mm}$ total length and of 90 to $110 \mathrm{mg}$ fresh weight were collected in the Roscoff Aber (N-Brittany). They were maintained in the laboratory for 1 or $2 \mathrm{wk}$ prior to metabolism measurements. During this acclimation period the shrimp were held in 12-1 plastic buckets (25 ind. bucket ${ }^{-1}$ ) individually supplied with running seawater from an open system. Salinity $(35 \% \mathrm{~S})$ and temperature $\left(18^{\circ} \mathrm{C}\right)$ were relatively constant over the test period. There was no sand on the bucket bottom in order to acclimate the shrimp to subsequent experimental conditions; absence of sand suppresses its diel activity rhythm (Hagerman, 1970). The shrimp were fed daily with crushed pieces of fresh Carcinus maenas.

\section{Metabolism measurements}

The shrimp were separated $12 \mathrm{~h}$ before starting the experiment into 10 groups of 20 , and each group was placed in a 6-1 jar filled with seawater; 5 of these were placed into a soundproof box, the others maintained in the culture room; none of the 2 groups received any food. At the beginning of the experiment, each group was checked, exuviae of the previous night were removed and numbered, and the shrimp were carefully rinsed with filtered seawater. Each group was then transferred into a 6-1 jar, previously rinsed with diluted $\mathrm{HCI}$, and completely filled with seawater filtered through $0,45 \mu \mathrm{m}$ mesh Millipore filter. The jars were sealed with laboratory film (Parafilm: American Company) avoiding any air bubbles. Five jars were returned to the soundproof box (C) and 5 others placed in a temperature regulated tank (E). Two control jars without shrimp were exposed to the same conditions. The jars were incubated at $18^{\circ} \mathrm{C}$ under controlled light conditions for $8 \mathrm{~h}$ (from 8.00 a.m. to $4.00 \mathrm{p} . \mathrm{m}$. every experimental day). At the end of this period the jars were gently shaken to homogenize the water; a water sample was taken from each jar for subsequent measurement of $\mathrm{O}_{2}$ concentration, and the ammonia content of the remainder was immediately determined using a Technicon autoanalyser. At the end of the experiment each group of shrimp was blotted on paper towels and weighed in a sealed box (double weighing to the nearest $\mathrm{mg}$ ). For experiments lasting several days, weight was measured a day before the actual experiment and on the last day of observation in order to minimize the stress. The duration of the incubation period was determined from preliminary experiments in which the excretion rate was checked every hour; this duration took into account water volume, shrimp fresh weight, temperature and adverse effects of excretory build-up. Ammonia production and oxygen consumption were calculated taking into account the difference in concentration between experimental and control jars.

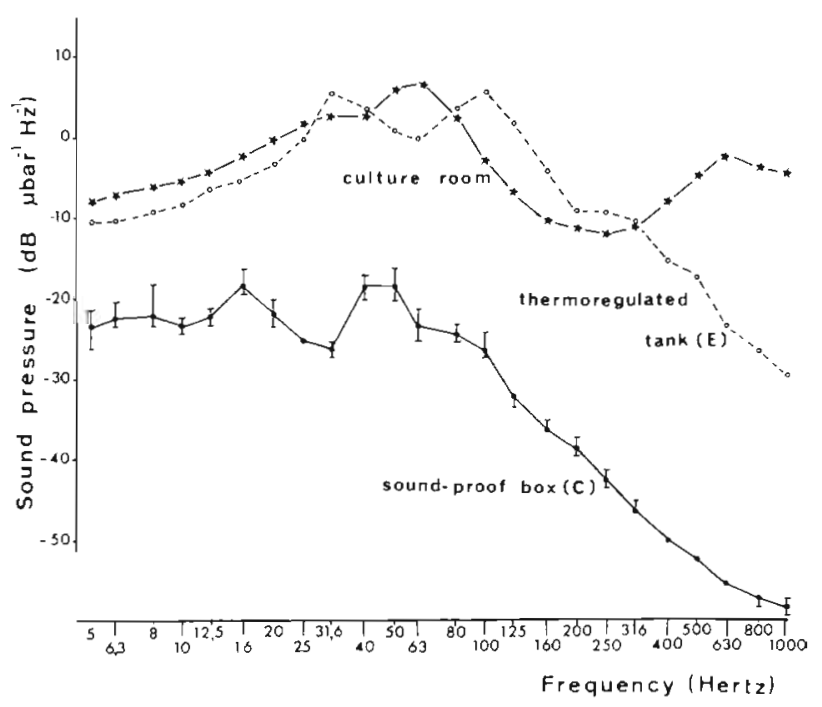

Fig. 1 Crangon crangon. Spectra of ambient noise recorded in experimental sound proof box (C), temperature-controlled tank $(E)$ and culture room 
Ammonia was determined by the colorimetric indophenol method (Solorzano, 1969) using a Technicon Autoanalyser II; the probe of the Technicon sampler was inserted directly into each jar. Standard solutions of $\left(\mathrm{NH}_{4}\right)_{2} \mathrm{SO}_{4}$ were prepared each day with the seawater used to fill the jars, giving the daily reference curve. Results were expressed as $\mu$ g-atom $\mathrm{NH}_{4}-\mathrm{N}$ g wet weight ${ }^{-1} \mathrm{~h}^{-1}$.

Oxygen was determined by titration according to Winkler's method using a Methrom Multidosimat E415. When the $\mathrm{O}_{2}$ content of seawater in a jar was below $75 \%$ of its initial value at the end of the incubation period, the data were discarded as oxygen consumption was disturbed by early effects of hypoxia. Results were expressed as $\mu \mathrm{l} \mathrm{O} \mathrm{O}_{2}$ wet weight ${ }^{-1} \mathrm{~h}^{-1}$.

\section{Noise measurements}

The recording equipment included a Brüel and Kjaer type 8101 hydrophone, a Brüel and Kjaer type 2606 measuring amplifier and a Nagra IV SJS tape recorder. The hydrophone was set inside a jar (similar as in experimental jars containing the shrimp). Hydrophone sensitivity was $36 \mathrm{~dB} \mu \mathrm{V}^{-1} \mu \mathrm{bar}^{-1}$ for $7.20 \mathrm{~m}$ cable length. Its frequency response was plane between $1 \mathrm{~Hz}$ and $20 \mathrm{kHz}$. Each recording lasted $10 \mathrm{~min}$ at $3.81 \mathrm{~cm}$ $\mathrm{s}^{-1}$ speed. At this speed the limits of response for the Nagra were $25 \mathrm{~Hz}$ to $3.5 \mathrm{kHz} \pm 1 \mathrm{~dB}$.

The $1 / 3$ octave band analysis of the recorded signal was achieved using a Brüel and Kjaer type 2307 level recorder after going through a Brüel and Kjaer 1621 pass band filter. Sound levels were recorded and compared with a reference signal traced on the level recorder. In each $1 / 3$ octave band a mean level for $60 \mathrm{~s}$ was taken. Values of sound level in $1 \mathrm{~Hz}$ bands (spectrum levels) were expressed as $\mathrm{dB} \mu \mathrm{bar}^{-1} \mathrm{~Hz}^{-1}$, those in wide bands as dB $\mu \mathrm{bar}^{-1}$.

\section{Environmental sound characteristics}

The soundproof box (C) used to reduce the laboratory background noise and to bring it to a level similar to that of in situ noise was the same model as the one described by Lagardère and Spérandio (1981). The sides were made of marine plywood lined with $A$ 10 insulating material. The box was separated from the ground by a concrete slab supported by inner tube tyres. It included two 55-1 tanks with circulating sea water in which the jars were placed during the incubation period. The light was programmed according to the natural photoperiod and did not exceed 200 Lux; the running water was kept between $17.5^{\circ}$ and $18^{\circ} \mathrm{C}$. In $\mathrm{C}$, the mean noise level was $-4 \mathrm{~dB}_{\mu b a r}{ }^{-1}$. The ambient noise spectrum (Fig. 1) exhibited a relative uniformity of the sound pressures going from 5 to 100 $\mathrm{Hz}$ (from -27 to $-20 \mathrm{~dB} \mu \mathrm{bar}^{-1} \mathrm{~Hz}^{-1}$ ). Beyond $100 \mathrm{~Hz}$, the sound pressure decreased gradually $\left(-5 \mathrm{~dB}_{\mu \mathrm{bar}}{ }^{-1}\right.$ $\mathrm{Hz}^{-1}$ at $1000 \mathrm{~Hz}$.

In the temperature-regulated tank (E) located in the measurement room, light conditions were similar to those in the soundproof box; a constant temperature of $18^{\circ} \mathrm{C}$ was set using a cryosystem and a thermomix. In $\mathrm{E}$, the mean noise level was $+25 \mathrm{~dB}$ $\mu_{\mathrm{bar}^{-1}}{ }^{-1}$. Fig, 1 shows that for all spectrum frequencies there is a marked increase in sound pressures compared to those recorded in the soundproof box. A mean $15 \mathrm{~dB}$ increase was observed for frequencies below

Table 1. Crangon crangon. Ammonia excretion rate in soundproof box $\mathrm{C}\left(=-4 \mathrm{~dB} \mu \mathrm{bar}^{-1}\right)$ and in thermoregulated tank $\mathrm{E}$ $\left(=+25 \mathrm{~dB} \mu \mathrm{bar}^{-1}\right)$. Each value represents a group of 20 similar sized shrimp, incubated at $18^{\circ} \mathrm{C}$ for $8 \mathrm{~h} \mathrm{(w.w.}=$ wet weight)

\begin{tabular}{|c|c|c|c|}
\hline \multirow[t]{2}{*}{ Date } & \multicolumn{2}{|c|}{$\begin{array}{c}\text { Excretion } \\
\left(\mu \mathrm{g}-\mathrm{at} \mathrm{NH}_{4}-\mathrm{Ng}^{-1} \mathrm{w} \cdot \mathrm{w} \cdot \mathrm{h}^{-1}\right)\end{array}$} & \multirow[t]{2}{*}{$\frac{\text { Erate }}{\text { Crate }}$} \\
\hline & $\mathrm{C}$ & E & \\
\hline \multirow{3}{*}{$7 / 10 / 80$} & 1.40 & 1.64 & \multirow{3}{*}{1.18} \\
\hline & 1.33 & 1.61 & \\
\hline & 1.31 & 1.52 & \\
\hline \multirow{2}{*}{$7 / 15 / 80$} & 1.49 & 1.84 & \multirow{2}{*}{1.24} \\
\hline & 1.42 & 1.77 & \\
\hline \multirow{3}{*}{$7 / 29 / 80$} & 1.27 & 1.42 & \multirow{3}{*}{1.21} \\
\hline & 1.11 & 1.35 & \\
\hline & 1.01 & 1.34 & \\
\hline \multirow{5}{*}{$7 / 10 / 81$} & 1.01 & 1.34 & \multirow{5}{*}{1.26} \\
\hline & 0.99 & 1.27 & \\
\hline & 0.93 & 1.22 & \\
\hline & 0.86 & 1.04 & \\
\hline & 0.74 & 0.84 & \\
\hline \multirow{5}{*}{$7 / 11 / 81$} & 1.47 & 1.77 & \multirow{5}{*}{1.20} \\
\hline & 1.35 & 1.67 & \\
\hline & 1.33 & 1.55 & \\
\hline & 1.28 & 1.41 & \\
\hline & 1.09 & 1.39 & \\
\hline \multirow{5}{*}{$7 / 21 / 81$} & 1.04 & 1.65 & \multirow{5}{*}{1.28} \\
\hline & 1.01 & 1.44 & \\
\hline & 0.99 & 1.16 & \\
\hline & 0.94 & 0.97 & \\
\hline & 0.84 & 0.94 & \\
\hline \multirow{4}{*}{$7 / 22 / 81$} & 1.18 & 1.46 & \multirow{4}{*}{1.12} \\
\hline & 1.13 & 1.18 & \\
\hline & 1.08 & 1.18 & \\
\hline & 1.03 & 1.10 & \\
\hline \multirow{5}{*}{$7 / 23 / 81$} & 1.55 & 2.10 & \multirow{5}{*}{1.24} \\
\hline & 1.27 & 1.45 & \\
\hline & 1.02 & 1.26 & \\
\hline & 1.02 & 1.20 & \\
\hline & 0.97 & 1.18 & \\
\hline $\begin{array}{l}\text { Mean vaiue } \\
\pm \text { S.E.M. }\end{array}$ & $\begin{aligned} & 1.139 \\
\pm & 0.0367\end{aligned}$ & $\begin{aligned} & 1.402 \\
\pm & 0.0505\end{aligned}$ & \\
\hline
\end{tabular}


$20 \mathrm{~Hz}$ and a 30 to $35 \mathrm{~dB}$ increase for frequencies between 31.5 and $100 \mathrm{~Hz}_{\text {; }}$ above $100 \mathrm{~Hz}$ the E sound pressure remained 25 to $30 \mathrm{~dB}$ higher than the $\mathrm{C}$ pressure.

In the culture room where the shrimp were acclimated immediately after collection, the mean

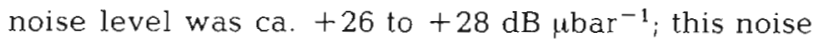
level and the related spectrum (Fig. 1) indicated that the shrimp were submitted to similar sound pressures in the culture room and in the experimental thermoregulated tank, at least for the frequency range between 5 and $400 \mathrm{~Hz}$.

\section{RESULTS}

\section{Influence of ambient noise on ammonia excretion}

Ammonia excretion was simultaneously measured at both $C$ and $E$ background noises. Experiments were conducted in July ' 80 and July' 81 ; excluding the last 2 experiments $(7 / 22 / 81+7 / 23 / 81)$, no similar test had been done previously on the shrimp. Table 1 shows for each 20-shrimp group the ammonia excretion rate expressed as $\mu \mathrm{g}$-atom $\mathrm{NH}_{4}-\mathrm{Nh}^{-1}$. Results related to any group showing more than 5 moults in the night before the experiment were discarded as the excretion rate of freshly moulted Crangon crangon (Stage A, according to Drach, 1939) is very high (Regnault, 1979).

The mean value ( \pm S.E.M.) of the excretion rate, calculated from the 32 measurements listed in Table 1 , was $1.40 \pm 0.05 \mu \mathrm{g}$ at $\mathrm{NH}_{4}-\mathrm{N} \mathrm{g}^{-1}$ wet weight for shrimp in the $\mathrm{E}$ environment, and $1.14 \pm 0.04$ for shrimp in the $\mathrm{C}$ environment. Confidence intervals, with $99 \%$ probability, were estimated according to the Student's $t$ distribution; they show that these 2 mean values are significantly different.

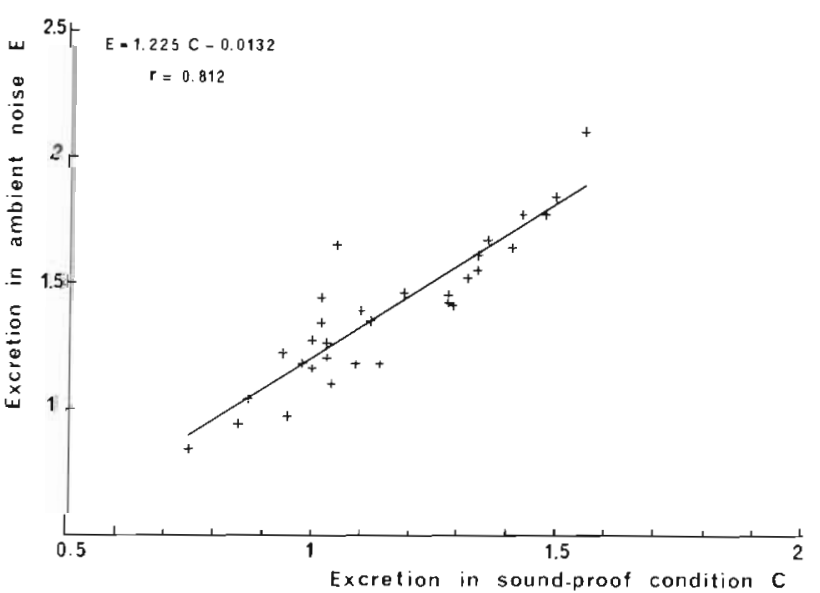

Fig. 2. Crangon crangon. Regression line showing relationship between excretion rates ( $\mu$ g-at $\mathrm{NH}_{4}-\mathrm{N} \mathrm{g}^{-1}$ wet weight $\mathrm{h}^{-1}$ ) in soundproof box (C) and in unprotected tank (E)
In the $E$ environment, ammonia excretion rate was always higher than that in the soundproof box. The increase varied from $18 \%$ to $28 \%$ according to the individual experiment. The relation between $\mathrm{E}$ rate and $C$ rate is represented by a regression line of the equation: $E=1.225 C-0.01329(r=0.812)$ (Fig. 2$)$. Thus, the influence of the background noise on ammonia excretion is clearly demonstrated for this species. It must be kept in mind that the slope of this regression line corresponds to a definite shrimp size group (mean wet weight: 90 to $110 \mathrm{mg}$ ).

Long-term effects of background noise Ievel on ammonia excretion and oxygen consumption

Initially, experimental shrimp were kept in the soundproof box for a limited period (12 $\mathrm{h}$ adaptation period before tests $+8 \mathrm{~h}$ incubation). Between these periods they were maintained in the culture room. The question is therefore: would shrimp continuously exposed to a steady noise level maintain a metabolic level at the initial rate or would they adapt? We maintained some shrimp for several days in the soundproof box, while at the same time some were exposed to $E$ ambient noise. Metabolic levels were estimated daily while measuring simultaneously ammonia excretion and oxygen consumption.

Experimental conditions were the same as those described above but, following excretion and respiration measurements, the shrimp were fed $1 \mathrm{~h}$ before each group was returned to its original noise level in new seawater. The first period of observations was conducted from 9 to 13 July, 1981 and totalled $108 \mathrm{~h}$ (shrimp mean weight: $98.5 \mathrm{mg}$ ); the second period, from 20 to 25 July, totalled $132 \mathrm{~h}$ (shrimp mean weight: $110 \mathrm{mg}$ ). Following the results obtained for the first series, the shrimp were given more food $(2 \mathrm{~h}$ long meals given in small containers in order to offer the shrimp a longer and better opportunity for contact with the food).

Fig. 3. shows the results obtained from each 20 shrimp group during the first series of experiments. The 5 groups placed in $E$ (or in $C$ ) displayed homogeneous rates of excretion and oxygen consumption.

\section{Ammonia excretion}

Mean excretion rates $\left(\mu \mathrm{g}\right.$ at $\mathrm{NH}_{4}-\mathrm{N} g$ wet weight ${ }^{-1}$ $\mathrm{h}^{-1}$ ) for shrimp kept several consecutive days in the unprotected tank (E) and in the soundproof box (C) are represented in Fig. 4 . In both experiments the rates were always higher in $E$ than in $C$. To quantify this deviation the $\mathrm{E}$ : $\mathrm{C}$ ratio ( $\mathrm{E}$ rate: $\mathrm{C}$ rate) was calculated. 
Fig. 3. Crangon crangon. Individual variations in rates of excretion and $\mathrm{O}_{2}$ consumption in 20-shrimp groups acclimated at 2 noise levels for $4 \mathrm{~d}$ (Expt. 1). $\mathrm{C}=-4 \mathrm{~dB} \mu^{-1} \mathrm{bar}^{-1}$; $E=+25 \mathrm{~dB}^{\mathrm{B}} \mathrm{bar}^{-1}$
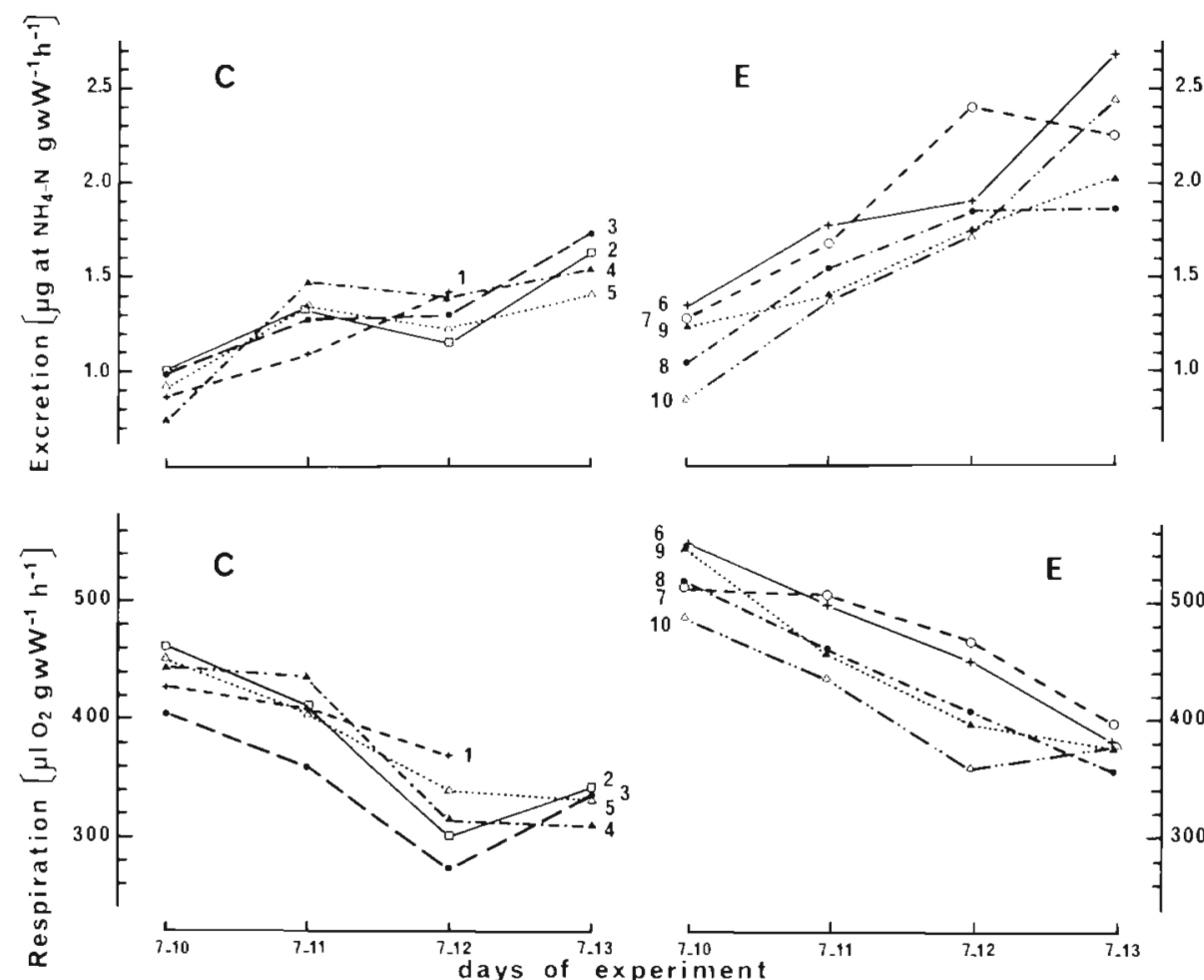

C<smiles>c1ccccc1</smiles>

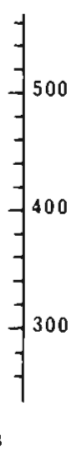

At the beginning of experiments (Day D1 to D2) the value of the $E$ : $C$ ratio was between 1.20 and 1.28 ; this value appeared to be characteristic for this size group. The difference between $\mathrm{E}$ and $\mathrm{C}$ increased from the third day on in Experiment $1(\mathrm{E}: \mathrm{C}=1.46)$. In Experiment 2, where shrimp received more food, this appeared a little later but by the 5th day a similar deviation was observed ( $\mathrm{E}: \mathrm{C}=1.44$ ) (Table 2).

The mean excretion rate also increased as a function of time. This increase was much more noticeable in the unprotected tank than in the soundproof box. It was also more marked in the first experiment than in the second one, but this might reflect the difference in feeding levels.

\section{Oxygen consumption}

Fig. 5 shows the changes in $\mathrm{O}_{2}$ consumption rates for shrimp kept in $\mathrm{E}$ and $\mathrm{C}$ for 4 to $5 \mathrm{~d}$. The rates $\left(\mu \mathrm{l} \mathrm{O}_{2} \mathrm{~g}\right.$ wet weight ${ }^{-1} \mathrm{~h}^{-1}$ ) were always higher in $\mathrm{E}$ than in $\mathrm{C}$. Initially, the E:C ratio was between 1.13 and 1.19 , slightly lower than the ratio observed simultaneously for excretion. In Experiment 1 the difference between $E$ and $C$ increased on the third day $(E: C=1.30)$; however, this increase was not confirmed the following day (Table 2). In Experiment 2 the $\mathrm{E}$ : $\mathrm{C}$ ratio fluctuated around 1.15 and increased only on the 5th day. Generally the $\mathrm{E}: \mathrm{C}$ ratio calculated for oxygen consumption appeared to be more stable than that for excretion rate.
The changes in $\mathrm{O}_{2}$ consumption, relative to the experimental duration, differed from those recorded for excretion. In Experiment 2, $\mathrm{O}_{2}$ consumption rate was rather constant and corresponded, for $\mathrm{E}$ and $\mathrm{C}$, to the rate found at the end of Experiment 1. The large drop in $\mathrm{O}_{2}$ consumption in Experiment 1 and the high first-day values will be discussed later.

Table 2. Crangon crangon. Variations of $\mathrm{E}: \mathrm{C}$ and $\mathrm{O}: \mathrm{N}$ ratios in shrimp acclimated at 2 noise levels for $4 d$ (Expt. 1) and $5 d$ (Expt. 2). The E:C ratio shows that rates of excretion and $\mathrm{O}_{2}$ consumption are always higher in the E environment than in the $\mathrm{C}$ environment. The atomic $\mathrm{O}: \mathrm{N}$ ratio is used as indicator of the metabolic substrate required for energy by the shrimp either in $\mathrm{E}$ or in $\mathrm{C}$

\begin{tabular}{|c|c|c|c|c|c|}
\hline \multicolumn{2}{|c|}{ Time (d) } & \multicolumn{2}{|c|}{$E: C$ ratio } & \multicolumn{2}{|c|}{$O: N$ ratio } \\
\hline & & $\begin{array}{c}\text { for } \\
\text { excretion }\end{array}$ & $\begin{array}{c}\text { for } \mathrm{O}_{2} \\
\text { consumpt. }\end{array}$ & in $\mathrm{C}$ & in $E$ \\
\hline \multirow{2}{*}{ D1 } & Expt. 1 & 1.25 & 1.19 & 43 & 41 \\
\hline & Expt. 2 & 1.28 & 1.13 & 29 & 26 \\
\hline \multirow{2}{*}{ D2 } & 1 & 1.20 & 1.17 & 28 & 27 \\
\hline & 2 & 1.22 & 1.08 & 26 & 24 \\
\hline \multirow{2}{*}{ D3 } & 1 & 1.46 & 1.30 & 22 & 19 \\
\hline & 2 & 1.23 & 1.17 & 23 & 22 \\
\hline \multirow{2}{*}{ D4 } & 1 & 1.42 & 1.14 & 18 & 15 \\
\hline & 2 & 1.41 & 1.13 & 23 & 18 \\
\hline \multirow{2}{*}{ D5 } & 1 & - & - & - & - \\
\hline & 2 & 1.44 & 1.22 & 18 & 16 \\
\hline
\end{tabular}




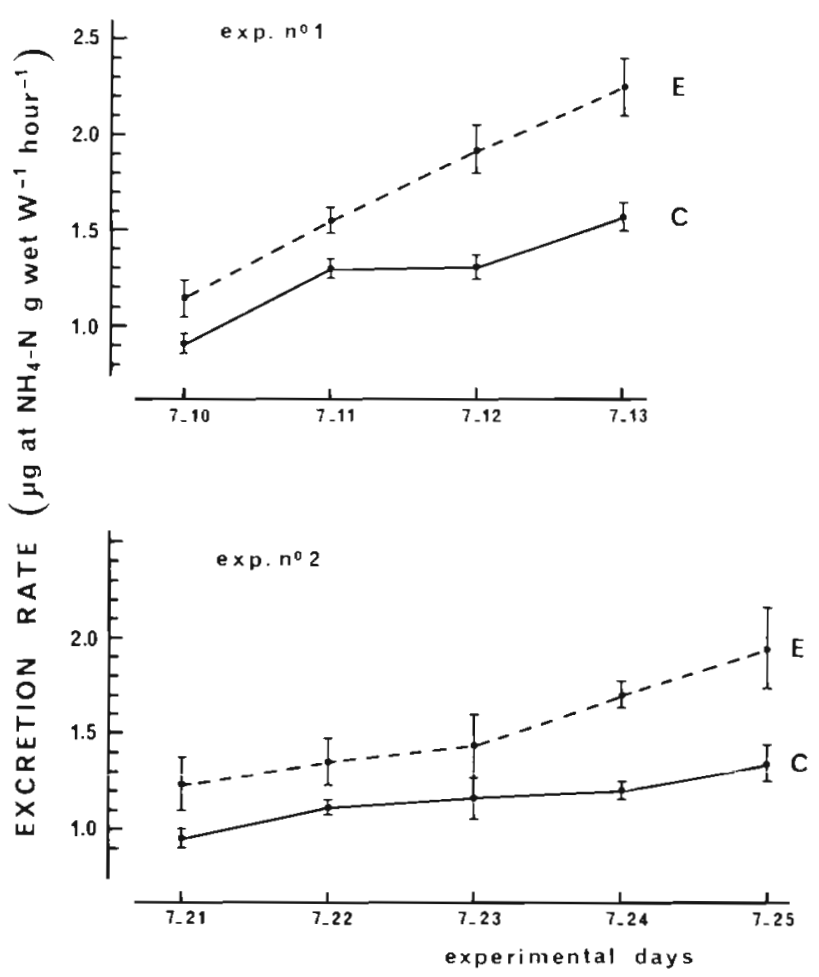

Fig. 4. Crangon crangon. Evolution of ammonia excretion rate in shrimp acclimated at 2 noise levels for $4 \mathrm{~d}$ (Expt. 1) and $5 \mathrm{~d}$ (Expt. 2). Mean values ( \pm S.E.M.: vertical bars) calculated from 5 groups of 20 shrimp each. $\mathrm{C}=-4 \mathrm{~dB} \mathrm{barr}^{-1} ; \mathrm{E}=$ $+25 \mathrm{~dB}^{+} \mathrm{bar}^{-1}$

\section{Atomic $O: N$ ratio}

The atomic $\mathrm{O}: \mathrm{N}$ ratio (consumed $\mathrm{O}_{2}$ : excreted $\mathrm{NH}_{4}-\mathrm{N}$ ) was calculated taking into account mean respiration and excretion rates. At the beginning of the experiments, excluding D1 in Experiment 1, the value of this ratio was between 25 and 28 ; that is the range usually observed in freshly collected Crangon crangon (Regnault, 1981a). From the 3rd day on, the O:N ratio decreased and, for each series of experiments, this change was more noticeable in $\mathrm{E}$ than in $\mathrm{C}$.

\section{DISCUSSION}

The Crangon crangon examined in this study were in their juvenile growth phase; they were collected from a shallow intertidal area exposed to tidal and meteorological effects but very low human perturbation. Considering ambient-noise-level estimations reported previously for the natural environment (see 'Introduction'), the sound pressure in the experimental soundproof box was in good agreement: between -27 and $-20 \mathrm{~dB} \mu \mathrm{bar}^{-1} \mathrm{~Hz}^{-1}$ in the 5 to $100 \mathrm{~Hz}$ frequency range (where the highest values were recorded)
(Fig. 1). The comparison of the spectra of ambient noise recorded in the soundproof box and under usual laboratory conditions reveals a marked difference of sound pressure in the whole frequency range considered (a mean $29 \mathrm{~dB}$ increment in the unprotected environment).

As acoustic stimuli, at suitable frequencies, are transmitted at time intervals, modifications of the cardiac rhythm have been observed in the lobster Homarus americanus (Offutt, 1970) and bursts of impulses from some interneurons in fiddler crabs (Salmon et al., 1977). Under laboratory conditions, acoustic stimulation is continuously imposed on the animals at high sound pressure levels. The effects of this stimulation were expected to be more important than those reported above. Therefore, we have studied the influence of the ambient noise level on metabolism: general metabolism and nitrogen metabolism through oxygen consumption and ammonia release respectively. All metabolic measurements were made in postdigestive periods (routine metabolism).

We observed that ammonia excretion was always higher at a noise level around $+25 \mathrm{~dB} \mu \mathrm{bar}^{-1}$ than at the background level of $-4 \mathrm{~dB} \mu \mathrm{bar}^{-1}$. The linear relation between the 2 excretion rates shows that this difference is very significant: whatever the excretion rate recorded in the soundproof box, under experimental conditions the rate will always be higher by an average of $22 \%$. Thus the shrimp is definitely influ-

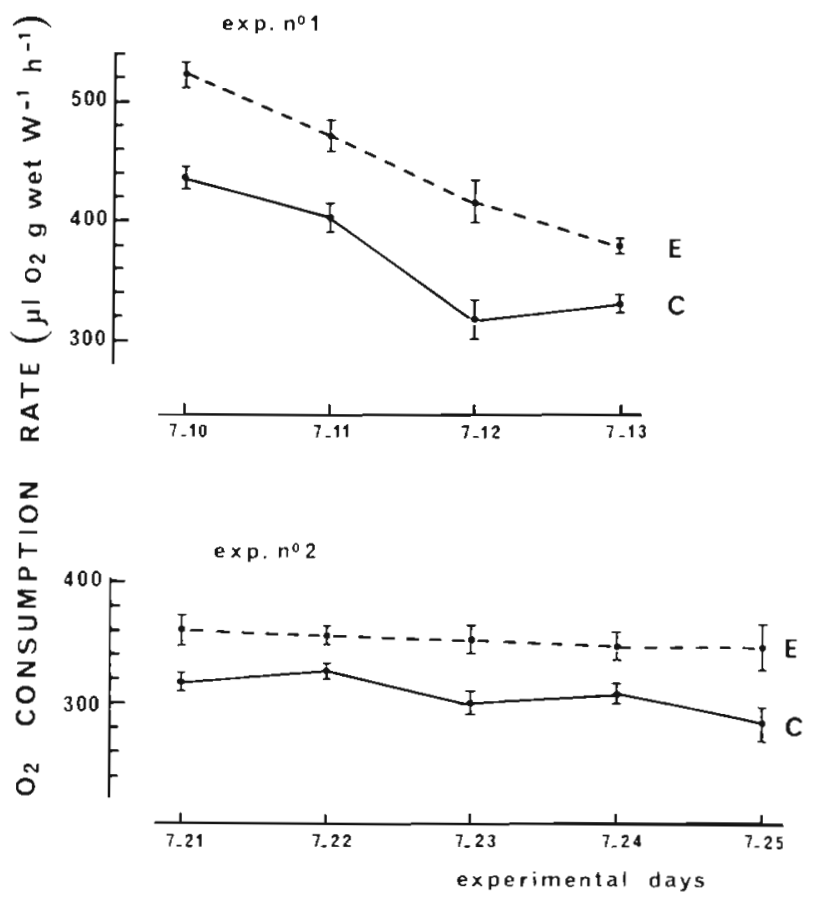

Fig. 5. Crangon crangon. Evolution of $\mathrm{O}_{2}$ consumption rate of shrimp acclimated at 2 noise levels for $4 \mathrm{~d}$ (Expt. 1) and $5 \mathrm{~d}$ (Expt. 2); see also legend to Fig. 4 
enced by the noise level of its environment; a sound pressure increment of around $30 \mathrm{~dB}$ increases its nitrogen metabolism noticeably. This means that in a laboratory (under rearing or experimental conditions), rates of excretion and nitrogen metabolism will be overestimated compared to the shrimp's probable performance in its natural environment.

In previous observations (Lagardère and Regnault, 1980) the difference between excretion rates in the unprotected environment and in the soundproof box was more pronounced as the mean value of the $E$ : C ratio was 1.40 . Several circumstances may explain the difference between our past and present results. On the one hand, the sound-level increments $(33 \mathrm{~dB}$ in 1979, $29 \mathrm{~dB}$ in 1980/81) and the ambient-noise spectra in the measurement room were different (the sound pressure being clearly higher on $100 \mathrm{~Hz}$ than on other frequencies in 1979). The quantitative and qualitative components of the sound pressure could have influenced the metabolic response of Crangon crangon, particularly if the shrimp were able to discriminate between individual frequency components of the signal. On the other hand, the shrimp studied in July 79 were younger and smaller and it seems not unlikely that the acoustic sensitivity of $C$. crangon could vary as a function of age and size. These 2 hypotheses require qualification.

The ambient noise level also influences the oxygen consumption rate. Shrimp placed at a $+25 \mathrm{~dB}_{\mu \mathrm{bar}}{ }^{-1}$ noise level consume 1.13 to 1.19 times more oxygen than those placed at $-4 \mathrm{~dB} \mu \mathrm{bar}^{-1}$. A $29 \mathrm{~dB}$-increment in sound pressure caused simultaneously an increase in rates of nitrogen excretion and oxygen consumption in conformity with the findings of Lagardère and Regnault (1980). However, the increase was rather less pronounced in respiration (15\% increase) than in excretion (22\% increase). When shrimp were kept over several consecutive days at the 2 noise levels, the difference in oxygen consumption between $\mathrm{E}$ and $\mathrm{C}$ was relatively constant but the difference in ammonia excretion became more pronounced with time. In $E$, the shrimp were exposed to a noise level unusually high compared to the natural environment, so they could have been expected to adapt to this stress and gradually bring their metabolism back to a steadystate level close to that observed here in the soundproof box. However there was no evidence for such adaptation. Indeed, the excretion of ammonia showed the opposite trend: compared to the beginning, a higher $\mathrm{E}$ : C ratio was obtained at the end of the experiments.

The changes in rates of excretion and oxygen consumption with time are different for the 2 series of experiments. In Experiment 1 there was a sharp increase in nitrogen excretion and a sharp drop in oxygen consumption. While similar changes were observed in Experiment 2, these were much less pronounced (Figs. 4 and 5): after 5 d there was a $28 \%$ increase in excretion and a $10 \%$ decrease in $\mathrm{O}_{2}$ consumption for shrimp in the soundproof box. The oxygen consumption rate recorded on D1 in Expt. 1 appeared abnormally high compared to the usual data obtained by one of us (M.R.) for this size-group and experimental temperature; this was corroborated by the value of the $O: N$ ratio $(=40)$ which was very seldom obtained. The present values for D1 are still unexplained but it must be kept in mind that the resulting drop in oxygen consumption between D1 and D2 in this experiment could be unreliable. Yet, between the 2 experiments the difference in results of excretion and respiration was significant. It is likely that the increased food supply of the shrimp in Expt. 2 accounts for this effect. Starvation effects on adult Crangon crangon have been observed as an increase in ammonia excretion and a simultaneous decrease in oxygen consumption, the consequent drop of the $O: N$ ratio disclosing a higher participation of body proteins in supplying the energy required (Regnault, 1981a).

A similarity in quality, if not in quantity, appeared between the effects of starvation in adults and the effects of insufficient feeding in juveniles. That was not surprising considering the importance of nitrogen metabolism for this carnivorous species and the decrease in its nitrogen requirements with age and size (Regnault and Luquet, 1974). In spite of the feeding level which could explain a metabolic response more marked in Expt. 1 than in Expt. 2, the changes observed with time might be due to experimental constraints. Through several consecutive days, changes in metabolic levels were more regular and more moderated in the soundproof box than in the unprotected environment. Furthermore, individual variability represented by standard deviations of means, was also less in the soundproof box.

In summary, the mean ambient noise level usually recorded in a laboratory actually influences the metabolism of Crangon crangon. Rates of ammonia excretion and oxygen consumption increase significantly compared to rates measured in a reduced noise background (quasi-natural conditions). The increased amplitude, which in this study was evaluated for a definite size group and a definite noise spectrum, is likely to vary according to shrimp age and characteristics of noise background. The shrimp react immediately to a new noise level; its metabolic response was the same after a few hours and after 4 to $5 \mathrm{~d}$.

Acknowledgements. The authors want to thank very much Miss Sineide Correia Silva for her friendly collaboration in July 1980 and Mrs. Isabelle Kühn for translation. 


\section{LITERATURE CITED}

Buerkle, U. (1977). Detection of trawling noise by Atlantic cod (Gadus morhua L.). Mar Behav. Physiol. 4: 233-242

Chapman, C. J., Hawkins, A. D. (1973). A field study of hearing in the cod, Gadus morhua L. J. comp. Physiol. 85: $147-167$

Chichibu, S. (1978a). Activities of the velocity-sensitive mechanoreceptor in the crayfish. Acta medica Kinki Univ. 3: $167-175$

Chichibu, S. (1978b). Response patterns and the direction sensitivities of the crayfish setae units. Acta medica Kinki Univ. 3: 177-189

Cohen, M., Dijkgraaf, S. (1961). Mechanoreception. In: Waterman, T. H. (ed.) The physiology of Crustacea, Vol. II, Sense organs, integration and behavior. Academic Press, New York, p. 65-108

Debaisieux, P. (1949). Les poils sensoriels d'Arthropodes et l'histologie nerveuse. I. Praunus flexuosus Müll. et Crangon crangon L. La Cellule 52: 311-360

Foxton, P. (1969). The morphology of the antennal flagellum of certain of the Penaeidea (Decapoda, Natantia). Crustaceana $16: 34-42$

Hagerman, L. (1970). Locomotory activity patterns of Crangon vulgaris (Fabricius) (Crustacea, Natantia). Ophelia 8: $255-266$

Hawkins, A. D., Anthony, P. D. (1981). Aquarium design. In: Hawkins, A. D. (ed.) Aquarium systems. Academic Press, London, p. 1-46

Horch, K. (1971). An organ for hearing and vibration sense in the ghost crab Ocypode. Z. vergl. Physiol. 73: 1-21

Lagardère, J. P., Regnault, M. (1980). Influence du niveau sonore de bruit ambiant sur le métabolisme de Crangon crangon (Decapoda, Natantia) en élevage. Mar Biol. 57: $157-164$

Lagardère, J. P., Spérandio, M. (1981). Influence du niveau sonore de bruit ambiant sur la croissance de la crevette Crangon crangon (Linné, 1758). Résultats préliminaires Aquaculture 24: 77-90

Lagardère, J. P. (1982). Effects of noise on growth and reproduction of Crangon crangon in rearing tanks. Mar. Biol. 71: $177-185$

Laverack, M. S. (1962a). Responses of cuticular sense organs of the lobster Homarus vulgaris (Crustacea). I. Hair peg organs as water current receptors. Comp. Biochem. Physiol. 5: 319-325

Laverack, M. S. (1962b). Responses of cuticular sense organs of the lobster, Homarus vulgaris (Crustacea). II. Hair-fan organs as pressure receptors. Comp. Biochem. Physiol. 6: $137-145$

Offutt, G. C. (1970). Acoustic stimulus perception by the American lobster Homarus americanus (Decapoda). Experientia 26: 1276-1278

Regnault, M. (1979). Ammonia excretion of the sand shrimp Crangon crangon (L.) during the moult cycle. J. comp. Physiol. 133: 199-204

Regnault, M. (1981a). Respiration and ammonia excretion of the shrimp Crangon crangon L: Metabolic responses to prolonged starvation. J. comp. Physiol. 141: 549-555

Regnault, M. (1981b). L'excrétion azotée chez le Crustacés et les facteurs l'influençant. Oceanis 7: 769-786

Regnault, M., Luquet, P. (1974). Besoins en protéines de la crevette grise Crangon crangon (L.) au cours de sa croissance. Annls Nutr. Aliment. 28: 523-537

Salmon, M., Horch, K., Hyatt, G. W. (1977). Barth's myochordonotal organ as a receptor for auditory and vibrational stimuli in fiddler crabs (Uca pugilator and $U$. minax). Mar Behav. Physiol. 4: 187-194

Solorzano, L. (1969). Determination of ammonia in natural waters by the phenolhypochlorite method. Limnol Oceangr. 14: 799-801

Tautz, J., Masters, W. M., Aicher, B., Markl. H. (1981). A new type of water vibration receptor on the crayfish antenna. I. Sensory physiology. J. comp. Physiol. 144: 533-541

Tautz, J., Sandeman, D. C. (1980). The detection of waterborne vibration by sensory hairs on the chelae of the crayfish. J. exp. Biol. 88: 351-356

Tazaki, K. (1977). Nervous responses from mechanosensory hairs on the antennal flagellum in the lobster, Homarus gammarus (L.). Mar. Behav. Physiol. 5: 1-18

Tazaki, K., Ohnishi, M. (1974). Responses from tactile receptors in the antenna of the spiny lobster Panulirus japonicus. Comp. Biochem. Physiol. 47A: 1323-1327

Vedel, J. P., Clarac, F. (1976). Hydrodynamic sensitivity by cuticular organs in the rock lobster Palinurus vulgaris. Mar. Behav. Physiol. 3: 235-251

Wenz, G. M. (1962). Acoustic noise in the ocean: spectra and sources. J. Acoust. Soc. Am. 34: 1936-1956 